\title{
Substantiation of agroecological factors on soybean agrophytocenoses by analysis of variance of the Right-Bank Forest- Steppe in Ukraine
}

\author{
I. Didur, M. Bakhmat, O. Chynchyk, H. Pantsyreva, N. Telekalo, O. Tkachuk \\ Vinnytsia National Agrarian University \\ Vinnytsia, Ukraine, State Agrarian and Engineering University in Podilia, Kamyanets-Podilsky, Ukraine \\ Corresponding author E-mail: apantsyreva@ukr.net
}

Received: 17.09.2020. Accepted: 17.10.2020

\begin{abstract}
We presented the analysis of agroecological factors, which provides development of regulations in the application of alternative fertilizers for soybean cultivation with short-term and long-term action. To establish the reliability of yield data by analysis of variance, it was determined that LSD 0.05 for factor A in 2017 was 0.09 t/ha. The largest deviations of yield indicators to control among varieties were: variety Podilska416 $-0.41 \mathrm{t} / \mathrm{ha}$, variety Chernivtsi $9-0.27$ t/ha and variety Agate -0.66 t/ha, which exceeded the value of $\mathrm{LSD}_{0.05}$ for the factor $A$ (soybean variety) by $0.32,0.18$ and 0.57 t/ha, respectively.

Keywords: Agroecological factors; Bioorganic varietal; Technology; Soybean; Cultivation
\end{abstract}

\section{Introduction}

The increase in soybean production in all growing zones is due to both the expansion of sown areas and, very importantly, the increase in its yield. However, as reported, A.V. Semtsov and A.O. Babich, the selection of a variety is of great importance in increasing the yield and improving the quality of soybean seeds. But, as noted by Myakushko Y., Baranov V., soybean varieties have a narrow ecological adaptation, so the technology of growing this crop should be based on the best, most adapted to the specific soil and climatic conditions of the zone, zoned and promising varieties of local selection. Academician A.O. Babich points out that for each soil-climatic zone a whole group of varieties is well zoned, well adapted to the conditions of the regions, they ripen reliably, provide high yields. At the same time, the author believes that the main areas of soybeans in the Forest-Steppe and Steppe should be occupied by medium-early and medium-ripe varieties that would effectively use the entire growing season. However, A.O. Babych and Petrichenko V.F. emphasize that it would be a mistake to think that soybeans can be grown everywhere in Ukraine. High soybean yields are possible only within the so-called soybean belt, outside of which its production without irrigation is risky, especially in the arid southeastern and southern regions. From the perspective, this strategic crop can be sown on a fairly large area of the right-bank and left-bank Forest-Steppe, Northern, Central and South-Western Steppe, Forest Steppe areas of Polissya and irrigated lands of the Southern Steppe. The creation of a soybean belt will mean a new stage in the production of soybean crops, will promote the biologization of agriculture, the production of environmentally friendly products. The basis of the soybean belt is varietal zoning and bioclimatic resources of the region.

There are no secondary measures in soybean cultivation technology. Any agronomic measure is important and necessary in its own way. Its influence on the final result - yield, can be manifested to a greater or lesser extent, depending on the growing conditions. In this regard, there is a need to study the competitive relationship in soybean agrobiocenoses as a factor that can be regulated by elements of varietal cultivation technology. To date, in the agricultural sciences, multidimensional analysis is given insufficient attention, so in our research, we decided to pay special attention to this. Cluster analysis is most often used in agronomic research. Unlike many other procedures, cluster analysis is used when the researcher does not have certain a priori hypotheses about the overall assescment of research options. The concept of cluster analysis is to determine the optimal value of the objective function among the initial set. Most clustering algorithms are based on the use of heuristic methods, so their choice is to obtain the most useful result.

\section{Materials and Methods}

Studies on the optimization of varietal agricultural techniques of soybean cultivation were carried out by establishing a field experiment in accordance with the generally accepted method of three-factor scheme in four repetitions. The sown area of the elementary plot was 29.16, the accounting area was $25 \mathrm{~m}^{2}$. The aim of the research was to study the influence of varieties, fertilizer rates and sowing methods on soybean yield. 


\section{Results and Discussion}

Table 1. Significance of the influence of variety, norms of mineral fertilizers and sowing method on soybean yield in 2017.

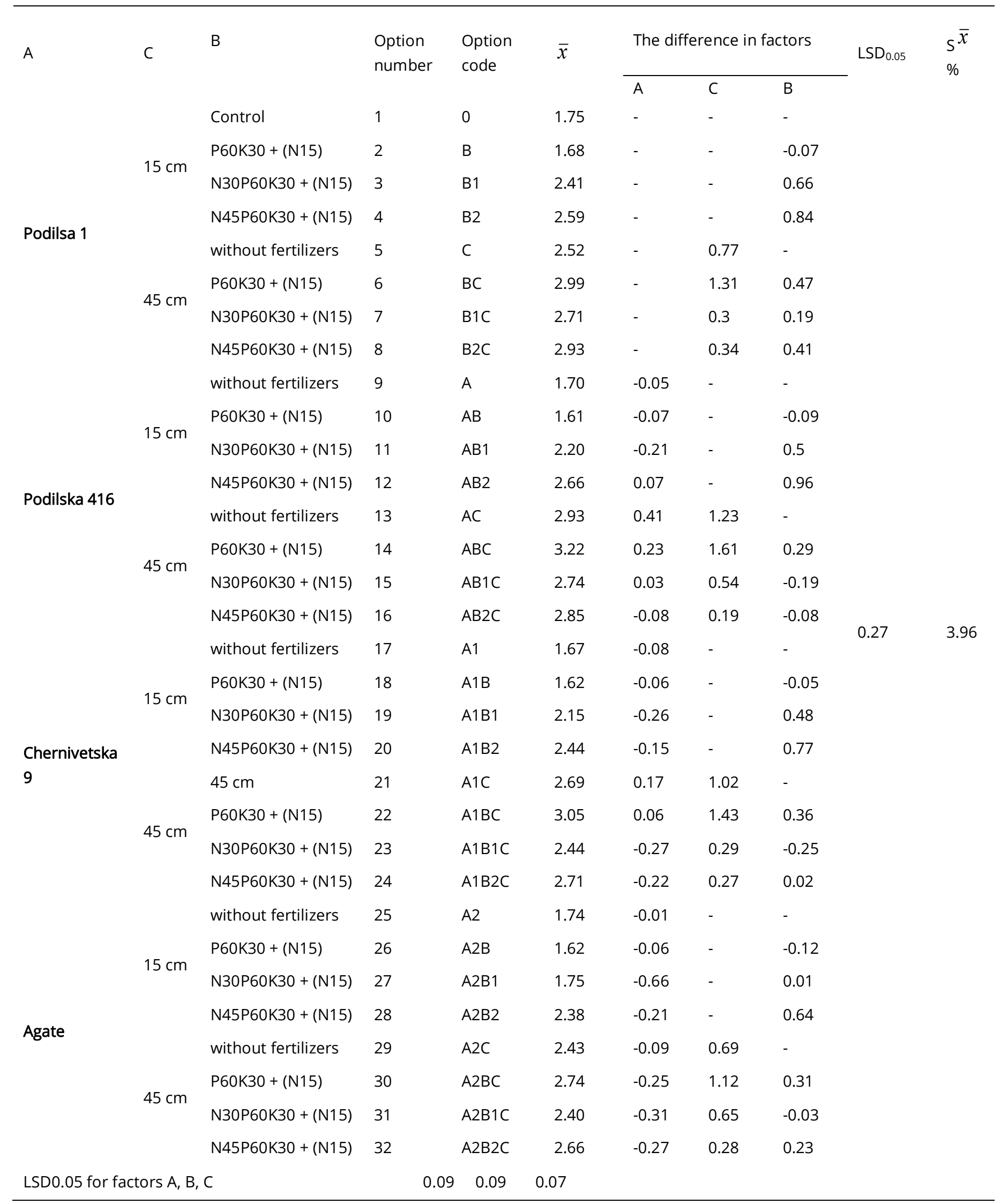

In agricultural research, cluster analysis is most often used in breeding and crop. To establish the reliability of yield data by analysis of variance, it was determined that LSD $_{0.05}$ for factor A in 2017 (Table 1) was 0.09 t/ha. The largest deviations of yield indicators to control among varieties were: variety Podilska416 - $0.41 \mathrm{t} / \mathrm{ha}$, variety Chernivetska9 - $0.27 \mathrm{t} / \mathrm{ha}$ and variety Agate - $0.66 \mathrm{t} / \mathrm{ha}$, which exceeded the value of $\mathrm{LSD}_{0.05}$ for the factor A (soybean variety) by $0.32,0.18$ and $0.57 \mathrm{t} / \mathrm{ha}$, respectively. 
Therefore, the variability of yield under the action of factor $A$ is significant. But in some embodiments, such as $9,10,12,15$, $16,17,18,22,25$, and 26 , the difference in factor $A$ is less than $\operatorname{LSD}_{0.05}(-0.05 ;-0.07 ; 0.07 ; 0.03 ;-0.08 ;-0.08 ;-0.06 ; 0.06 ;-0.01 ;-$ 0.06 and 0.09). Therefore, the influence of factor $A$ on the background of options $A B, A B 2, A B 1 C, A B 2 C, A 1, A 1 B, A 1 B C, A 2, a n d$ $A 2 B$ is not significant, but is within the error of the experiment. For factor $C$ (sowing method) $L_{S D} 0.05$ was also determined at the level of $0.09 \mathrm{t} / \mathrm{ha}$ and the largest deviations in the level of yield among sowing methods were in the wide-row method and were 1.61 and 0.27 t/ha, respectively, which exceeded the value of LSD $_{0.05}$ for factor $B$ by $+1.52 \mathrm{t} / \mathrm{ha}$ and $+0.18 \mathrm{t} / \mathrm{ha}$.

Table 2. Significance of the influence of variety, norms of mineral fertilizers and sowing method on soybean yield in 2018.

\begin{tabular}{|c|c|c|c|c|c|c|c|c|c|c|}
\hline \multirow{2}{*}{$A$} & \multirow{2}{*}{$\mathrm{C}$} & \multirow{2}{*}{ B } & \multirow{2}{*}{$\begin{array}{l}\text { Option } \\
\text { number }\end{array}$} & \multirow{2}{*}{$\begin{array}{l}\text { Option } \\
\text { code }\end{array}$} & \multirow{2}{*}{$\bar{x}$} & \multicolumn{3}{|c|}{ The difference in factors } & \multirow{2}{*}{$\mathrm{LSD}_{0.05}$} & \multirow{2}{*}{$\begin{array}{l}\mathrm{s}^{\bar{x}} \\
\%\end{array}$} \\
\hline & & & & & & $A$ & C & B & & \\
\hline \multirow{8}{*}{ Podilska 1} & \multirow{6}{*}{ 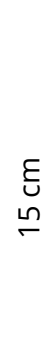 } & control & 1 & 0 & 1.43 & - & - & - & & \\
\hline & & P60K30 + (N15) & 2 & B & 1.59 & - & - & 0.16 & & \\
\hline & & N30P60K30 + (N15) & 3 & B1 & 2.03 & - & - & 0.6 & & \\
\hline & & N45P60K30 + (N15) & 4 & B2 & 2.19 & - & - & 0.76 & & \\
\hline & & without fertilizers & 5 & C & 2.41 & - & 0.98 & - & & \\
\hline & & P60K30 + (N15) & 6 & $\mathrm{BC}$ & 2.63 & - & 1.04 & 0.22 & & \\
\hline & \multirow{3}{*}{ 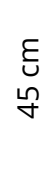 } & N30P60K30 + (N15) & 7 & B1C & 2.31 & - & 0.28 & -0.1 & & \\
\hline & & N45P60K30 + (N15) & 8 & $\mathrm{~B} 2 \mathrm{C}$ & 2.60 & - & 0.41 & 0.19 & & \\
\hline \multirow{9}{*}{ Podilska 416} & & without fertilizers & 9 & A & 1.51 & 0.08 & - & - & & \\
\hline & \multirow{5}{*}{$\begin{array}{l}E \\
\qquad \\
\stackrel{n}{-}\end{array}$} & P60K30 + (N15) & 10 & $A B$ & 1.68 & 0.09 & - & 0.17 & & \\
\hline & & N30P60K30 + (N15) & 11 & $A B 1$ & 2.22 & 0.19 & - & 0.71 & & \\
\hline & & N45P60K30 + (N15) & 12 & $\mathrm{AB} 2$ & 2.29 & 0.1 & - & 0.78 & & \\
\hline & & without fertilizers & 13 & $A C$ & 2.58 & 0.17 & 1.07 & - & & \\
\hline & & P60K30 + (N15) & 14 & $A B C$ & 2.68 & 0.05 & 1.0 & 0.1 & & \\
\hline & \multirow{3}{*}{ 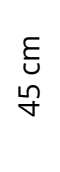 } & N30P60K30 + (N15) & 15 & $\mathrm{AB1C}$ & 2.50 & 0.19 & 0.28 & -0.08 & & \\
\hline & & N45P60K30 + (N15) & 16 & $\mathrm{AB} 2 \mathrm{C}$ & 2.75 & 0.15 & 0.46 & 0.17 & 026 & 430 \\
\hline & & without fertilizers & 17 & A1 & 1.43 & 0 & - & - & & \\
\hline \multirow{7}{*}{$\begin{array}{l}\text { Chernivetska } \\
9\end{array}$} & \multirow{5}{*}{$\begin{array}{l}E \\
\text { E } \\
\stackrel{n}{\leftarrow}\end{array}$} & P60K30 + (N15) & 18 & A1B & 1.51 & -0.08 & - & 0.08 & & \\
\hline & & N30P60K30 + (N15) & 19 & A1B1 & 1.95 & -0.08 & - & 0.52 & & \\
\hline & & N45P60K30 + (N15) & 20 & A1B2 & 2.09 & -0.1 & - & 0.66 & & \\
\hline & & without fertilizers & 21 & $\mathrm{~A} 1 \mathrm{C}$ & 2.38 & -0.03 & 0.95 & - & & \\
\hline & & P60K30 + (N15) & 22 & $\mathrm{~A} 1 \mathrm{BC}$ & 2.44 & -0.19 & 0.93 & 0.06 & & \\
\hline & \multirow{3}{*}{$\begin{array}{l}\varepsilon \\
\text { ปุ } \\
\text { ก }\end{array}$} & N30P60K30 + (N15) & 23 & A1B1C & 2.41 & 0.1 & 0.46 & 0.03 & & \\
\hline & & N45P60K30 + (N15) & 24 & $\mathrm{~A} 1 \mathrm{~B} 2 \mathrm{C}$ & 2.49 & -0.11 & 0.32 & 0.11 & & \\
\hline \multirow{8}{*}{ Agate } & & without fertilizers & 25 & A2 & 1.36 & -0.07 & - & - & & \\
\hline & \multirow{5}{*}{$\begin{array}{l}\varepsilon \\
\text { Un }\end{array}$} & P60K30 + (N15) & 26 & A2B & 1.52 & -0.07 & - & 0.16 & & \\
\hline & & N30P60K30 + (N15) & 27 & A2B1 & 1.59 & -0.44 & - & 0.23 & & \\
\hline & & N45P60K30 + (N15) & 28 & A2B2 & 2.21 & 0,02 & - & 0,85 & & \\
\hline & & without fertilizers & 29 & $\mathrm{~A} 2 \mathrm{C}$ & 2.33 & $-0,08$ & 0,97 & - & & \\
\hline & & P60K30 + (N15) & 30 & $\mathrm{~A} 2 \mathrm{BC}$ & 2.68 & 0,05 & 1,16 & 0,35 & & \\
\hline & \multirow{2}{*}{$\begin{array}{l}\varepsilon \\
\text { U } \\
\text { ஸे }\end{array}$} & N30P60K30 + (N15) & 31 & A2B1C & 2.20 & $-0,11$ & 0,61 & $-0,13$ & & \\
\hline & & N45P60K30 + (N15) & 32 & $\mathrm{~A} 2 \mathrm{~B} 2 \mathrm{C}$ & 2.54 & $-0,06$ & 0,33 & 0,21 & & \\
\hline \multicolumn{3}{|c|}{$\mathrm{LSD}_{0.05}$ for factors $\mathrm{A}, \mathrm{B}, \mathrm{C}$} & 0.09 & 0.09 & 0.07 & & & & & \\
\hline
\end{tabular}


Therefore, the increase in soybean yield due to the action of factor $\mathrm{C}$ (sowing method) is significant. It is also worth noting that in all cases, the difference in factor $C$ is greater than $L S D_{0.05}$. Thus, the effect of any of the interactions on the background of factor $C$ is not within the error.

Factor $\mathrm{B}$ (mineral fertilizer rate) also significantly affected soybean yields and this is indicated by the largest deviations among the mineral fertilizer rates N45P60K30 + (N15) and N30P60K30 + (N15), which were $+0.96 \mathrm{t} / \mathrm{ha}$ and $-0.25 \mathrm{t} / \mathrm{ha}$, which is more than $\mathrm{LSD}_{0.05}$ for factor $\mathrm{B}$ by $+0.89 \mathrm{t} / \mathrm{ha}$ and $-0.18 \mathrm{t} / \mathrm{ha}$, but in options $24 ; 27 ; 31$ the difference in factor $\mathrm{B}$ is less than $\mathrm{LSD}_{0.05}$ $(0.02,0.01,0.03,0.07)$. Thus, the influence of factor $B$ on the background of variants $A 1 B 2 C, A 2 B 1, A 2 B 1 C$ is not significant, but is within the error.

In addition, Fisher's actual criteria for factors A, B and C are 13.45, 237.07 and 43.76, respectively, which is more than the theoretical F0.95. Therefore, the null hypothesis HO: $d=0$ - is rejected. Based on this, we can conclude that the influence of the variety, the rate of mineral fertilizers and the method of soybean sowing is reliable; Fisher's actual criteria for the interaction of factors $A B$ and $B C$ are 3.21 and 10.50, which is greater than Fteor., so the interaction of these factors should also be considered reliable. For the rest of the interactions of AC and ABC factors, Fisher's criteria are in the range of 0.28 and 0.88 , which is much less than the theoretical indicators. Therefore, the interaction of combinations of these factors is unreliable. $\mathrm{LSD}_{0.05}$ for the whole experiment was determined at the level of $0.27 \mathrm{t} / \mathrm{ha}$. The value of the relative error (3.96\%) indicates the high accuracy of the experiment.

In 2018 , according to the analysis of variance of soybean yield data, it was found that $\mathrm{LSD}_{0.05}$ for factor A (Table 2 ) was also 0.09 t/ha. The largest deviations of yield indicators to control among varieties were: variety Podilska416 - 0.19 t/ha, variety Chernivetska9 - 0.19 t/ha and variety Agate $-0.44 \mathrm{t} / \mathrm{ha}$, which exceeded the value of LSD $_{0.05}$ for the factor and (soybean variety) by $0.10,0.10$ and $0.35 \mathrm{t} / \mathrm{ha}$, respectively.

Therefore, the variability of yield under the action of factor $A$ is significant. But in some embodiments, such as $9,14,17,18$, $19,21,25,26,28,29,30$, and 32 , the difference in factor $A$ is less than $L_{S D_{0.05}}(0.08 ; 0.05 ; 0,0 ;-0.08 ;-0.08 ;-0.03 ;-0.07 ;-0.07$; $0.02 ;-0.08 ; 0.05 ;-0.06$ and 0.09 ). Therefore, the influence of factor $A$ on the background of variants $A B C, A 1, A 1 B, A 1 B 1, A 1 C$, $A 2, A 2 B, A 2 B 2, A 2 C, A 2 B C, A 2 B 2 C$ is not significant, but is within the error of the experiment.

For factor C (sowing method) $L_{S D_{0.05}} 5$ was also determined at the level of $0.09 \mathrm{t} / \mathrm{ha}$ and the largest deviations of the yield level among sowing methods were in the wide-row method and were respectively 1.16 and $0.28 \mathrm{t} / \mathrm{ha}$, which exceeded the value of LSD 0,05 for factor B by $+1.07 \mathrm{t} / \mathrm{ha}$ and $+0.19 \mathrm{t} / \mathrm{ha}$. Therefore, the increase in soybean yield due to the action of factor $\mathrm{C}$ (sowing method) is significant. It is also worth noting that in all cases, the difference in factor C is greater than LSD 0.05 . Thus, the effect of any of the interactions on the background of factor $\mathrm{C}$ is not within the error.

Factor B (mineral fertilizer rate) also significantly affected soybean yields and this is indicated by the largest deviations among the mineral fertilizer rates N45P60K30 + (N15) and N30P60K30 + (N15), which were $+0.85 \mathrm{t} / \mathrm{ha}$ and $-0.13 \mathrm{t} / \mathrm{ha}$, which is more than LSD 0.05 for factor B by $+0.78 \mathrm{t} / \mathrm{ha}$ and $-0.06 \mathrm{t} / \mathrm{ha}$, but in options 22; 23 the difference in factor $B$ is less than LSD 0.05 $(+0.06 ;+0.03<0.07)$. Thus, the influence of factor $B$ on the background of variants $A 1 B C, A 1 B 1 C$ is not significant, but is within the error.

In addition, Fisher's actual criteria for factors A, B and C are 9.06, 208.57 and 38.92, respectively, which is more than the theoretical values of F 0.95. Therefore, the null hypothesis $\mathrm{HO}: \mathrm{d}=0$ - is rejected. Based on this, we can conclude that the influence of the variety, the rate of mineral fertilizers and the method of soybean sowing is reliable; Fisher's actual criteria for the interaction of $A C$ factors are 3.37, which is greater than $F$ teor., so the interaction of these factors should also be considered reliable. For the rest of the interactions of the factors $A B, B C$ and $A B C$, Fisher's criteria are in the range of 0.58 0.74 , which is much less than the theoretical indicators. Therefore, the interaction of combinations of these factors is unreliable.

$\mathrm{LSD}_{0.05}$ for the whole experiment was determined at the level of $0.26 \mathrm{t} / \mathrm{ha}$. The value of the relative error (4.30\%) indicates the high accuracy of the experiment.

According to the analysis of variance of soybean yield data in 2019, it was found that LSD 0.05 for factor A (Table 3) was 0.10 $\mathrm{t} / \mathrm{ha}$. The largest deviations of yields to control among varieties were: cultivar Podilska416 - $0.37 \mathrm{t} / \mathrm{ha}$, cultivar Chernivtsi9 $0.32 \mathrm{t} / \mathrm{ha}$ and cultivar Agate $-0.28 \mathrm{t} / \mathrm{ha}$, which exceeded the value of LSD 0.05 for factor A (soybean cultivar) by $0,27,0.22$ and $0.18 \mathrm{t} / \mathrm{ha}$, respectively. Therefore, the variability of yield under the action of factor $\mathrm{A}$ is significant. But in some embodiments, such as $13,17,18,19,20,21,24,30,31,32$, the difference in factor $A$ is less than LSD $0.05(0.08,0.04,0.05,0.05,0.04,0.04,0$, $0.02,0.06,0.06<0.10$ ). Therefore, the influence of factor $A$ on the background of variants $A S, A 1, A 1 B, A 1 B 1, A 1 B 2, A 1 C$, $A 1 B 2 C, A 2 B C, A 2 B 1 C$, and A2B2C is not significant, but is within the error of the experiment.

For factor C (sowing method) HIP 0.05 was also determined at the level of $0.10 \mathrm{t} / \mathrm{ha}$ and the largest deviations of the yield level among sowing methods were in the wide-row method and were 1.21 and $0.2 \mathrm{t} / \mathrm{ha}$, respectively, which exceeded the value of $\mathrm{LSD}_{0.05}$ for factor $\mathrm{B}$ by $+1.11 \mathrm{t} / \mathrm{ha}$ and $+0.1 \mathrm{t} / \mathrm{ha}$. Therefore, the increase in soybean yield due to the action of factor $\mathrm{C}$ (sowing method) is significant. It is also worth noting that in all cases, the difference in factor C is greater than LSD 0.05 . Thus, the effect of any of the interactions on the background of factor $\mathrm{C}$ is not within the error.

Factor $\mathrm{B}$ (mineral fertilizer rate) also significantly affected soybean yields and this is indicated by the largest deviations among mineral fertilizer rates N45P60K30 + (N15) and N30P60K30 + (N15), which were $1.06 \mathrm{t} /$ ha and $0.27 \mathrm{t} / \mathrm{ha}$, which is more than HIP0.05 for factor B by 0.99 t/ha and 0.2 t/ha, but in options $8 ; 23$ the difference in factor B is less than LSD $_{0.05}(0.03,0.01$ $<0.07$ ).

Thus, the influence of factor B on the background of variants B2C, A1B1C is not significant, but is within the error. In addition, Fisher's actual criteria for factors A, B and C are 10.31, 200.70 and 28.39, respectively, which is more than the theoretical F0.95. Therefore, the null hypothesis HO: $d=0$ - is rejected. Based on this, we can conclude that the influence of 
the variety, the rate of mineral fertilizers and the method of soybean sowing is reliable; Fisher's actual criteria for the interaction of $\mathrm{AC}$ factors are 4.02, which is greater than F teor., so the interaction of these factors should also be considered reliable. For the rest of the interactions of factors $A B, B C$ and $A B C$ Fisher's criteria are in the range of 0.26-0.81, which is much less than the theoretical indicators. Therefore, the interaction of combinations of these factors is unreliable. LSD 0.05 for the whole experiment was determined at the level of $0.28 \mathrm{t} / \mathrm{ha}$. The value of the relative error (3.83\%) indicates the high accuracy of the experiment.

Given the obtained results of the reliability of the influence of experimental factors on LSD 0.05 , we found that the largest number of unreliable differences was determined by factor $A$ and their number fluctuated over the years of research within 10-12 variants of the experiment or it was 31.25-37.5\% of the total number of options studied. Therefore, on the basis of the defined, it is possible to state that the investigated grades in the conditions of region provide rather close levels of productivity. In addition, we also found that over the years of research in options 17 (A1) and 18 (A1B) there was a constant unreliability of variability in yield levels.

Thus, this gives us reason to say that when growing soybeans in the region it is possible to successfully replace the variety Podilska 1 variety Chernivetska 9 and the most ambiguous will be the level of yield when growing varieties Podilska 416 and Agate.

When analyzing the reliability of factor B by LSD 0.05, it was found that the number of unreliable variants of the experiment was in the range of $2-3$ or $6.25-9.38 \%$ of the total number of variants of the experiment. Thus, the influence of mineral fertilizer rates on soybean yield in the zone is much more significant compared to varieties. We also found that the 23 (A1B1C) variant, where the norm N30P60K30 + (N15) was applied, was most often unreliable. Therefore, in view of the above, we can say that the application of this rate of mineral fertilizers can provide a stable and stable increase in yield. With regard to factor C, the analysis of reliability for LSD 0.05 did not reveal any unreliable option and it should be noted that all differences were positive in favor of wide-row $(45 \mathrm{~cm})$ method of sowing. Thus, according to the results of the research, we received an unequivocal statement that in the conditions of the region the best way of sowing soybeans is wide-row with a row spacing of $45 \mathrm{~cm}$.

\section{Conclusion}

The results of analysis of soybean yield in the experiment showed that varieties, rates of mineral fertilizers and sowing methods significantly affected the variability of the amount of grain, but in addition, we also determined the share of factors studied on soybean yield in the experiment to identify dependence of productivity formation and features of interrelations of factors and on this basis to optimize varietal agrotechnics of cultivation of this agricultural crop in the region. Thus, under the influence of hydrothermal conditions during the study period, the share of factors in the experiment changed. This was established by calculating the share of the factor in the total variance at a reliability level of $P=0.95$ according to Fisher's test. Thus, the most significant effect on soybean yield in the conditions of the Right-Bank Forest-Steppe of Ukraine was the norm of mineral fertilizers and among its gradations the norm N30P60K30 + (N15) contributed to the best level of yield of this agricultural crop.

\section{References}

Bandura, V., Mazur, V., Yaroshenko, L., Rubanenko, O. (2019). Research on sunflower seeds drying process in a monolayer tray vibration dryer based on infrared radiation. INMATEN - Agricultural Engineering, 5, 233-242.

Didur, I.M., Prokopchuk, V.M., Pantsyreva H.V. (2019). Investigation of biomorphological and decorative characteristics of ornamental species of the genus Lupinus L. Ukrainian Journal of Ecology, 9(3), 287-290. DOI: 10.15421/2019_743

Kaletnik G. (2018), Production and use of biofuels: Second edition, supplemented: textbook. Vinnytsia: LLC. Nilan-Ltdll, 336 p.

Kaletnik G., Honcharuk I., Yemchyk T., Okhota Y. (2020). The World Experience in the Regulation of the Land Circulation. European Journal of Sustainable Development, 9 (2), 557-568.

Kaletnik H., Prutska O., Pryshliak N. (2014). Resource potential of bioethanol and biodiesel production in Ukraine. Visegrad Journal on Bioeconomy and Sustainable Development, 1, 9-12.

Kaletnik, G., Honcharuk, I. \& Okhota, Y. (2020). The Waste-Free Production Development for the Energy Autonomy Formation of Ukrainian Agricultural Enterprises. Journal of Environmental Management and Touricm, XI, 3(43), 513-522.

Mazur V.A., Didur I.M., Pantsyreva H.V., Telecalo N.V. (2018a). Energy-economic efficiency of growth of grain-crop cultures in the conditions of right-bank Forest-Steppe zone of Ukraine. Ukrainian Journal of Ecology, 8(4), 26-33.

Mazur V.A., Mazur K.V., Pantsyreva H.V., Alekseev O.O. (2018b). Ecological and economic evaluation of varietal resources Lupinus albus L. in Ukraine Ukrainian Journal of Ecology, 8(3), 148-153.

Mazur, V. A., Myalkovsky, R.O., Mazur, K. V., Pantsyreva, H. V., Alekseev, O.O. (2019a). Influence of the Photosynthetic Productivity and Seed Productivity of White Lupine Plants. Ukrainian Journal of Ecology, 9(4), 665-670. DOI: 10.15421/2019_807

Mazur, V., Didur, I., Myalkovsky, R., Pantsyreva, H., Telekalo, N., Tkach, O. (2020a). The productivity of intensive pea varieties depending on the seeds treatment and foliar fertilizing under conditions of right-bank forest-steppe Ukraine. Ukrainian Journal of Ecology, 10(1), 101-105. 
Mazur, V.A, Mazur, K.V., Pantsyreva, H.V. (2019b). Influence of the technological aspects growing on quality composition of seed white lupine (Lupinus albus L.) in the Forest Steppe of Ukraine Ukrainian Journal of Ecology, 9, 50-55.

Mazur, V.A., Branitskyi, Y.Y., Pantsyreva, H.V. (2020b). Bioenergy and economic efficiency technological methods growing of switchgrass. Ukrainian Journal of Ecology, 10(2), 8-15.

Mazur, V.A., Pantsyreva, H.V., Mazur, K.V., \& Monarkh, V.V. (2019c). Ecological and biological evaluation of varietal resources Paeonia L. in Ukraine. Acta Biologica Sibirica, 5(1), 141-146. https://doi.org/10.14258/abs.v5.i1.5350

Mazur, V.A., Pantsyreva, H.V., Mazur, K.V., Didur, I.M. (2019d). Influence of the assimilation apparatus and productivity of white lupine plants. Agronomy Research, 17, 206-219. https://doi.org/10.15159/AR.19.024

Mazur, V.A., Pantsyreva, H.V., Mazur, K.V., Myalkovsky, R.O., Alekseev, O.O. (2020c). Agroecological prospects of using corn hybrids for biogas production. Agronomy Research 18(1), 177-182.

Monarkh, V.V., Pantsyreva, H.V. (2019). Stages of the Environmental Risk Assescment. Ukrainian Journal of Ecology, 9(4), 484492. DOI: $10.15421 / 2019 \_779$

Palamarchuk, V., Telekalo, N. (2018). The effect of seed size and seeding depth on the components of maize yield structure. Bulgarian Journal of Agricultural Science, 24(5), 2018. 785-792.

Palamarchuk, V., Honcharuk, I., Honcharuk, T. \& Telekalo, N. (2018). Effect of the elements of corn cultivation technology on bioethanol production under conditions of the right-bank forest-steppe of Ukraine. Ukrainian Journal of Ecology, 8(3), 4753.

Pantsyreva, H.V. (2017). Formation of grain productivity of white lupine depending on technological methods in the right-bank forest-steppe. Dissertation for obtaining a scientific degree of the candidate of agricultural sciences. Kam'ianets-Podilskyi, 100-101.

Pantsyreva, H.V. (2019). Morphological and ecological-biological evaluation of the decorative species of the genus Lupinus L. Ukrainian Journal of Ecology, 9(3), 74-77. DOI: 10.15421/2019_711

Pantsyreva, H.V., Myalkovsky, R.O., Yasinetska, I.A., Prokopchuk V.M. (2020). Productivity and economical appraisal of growing raspberry according to substrate for mulching under the conditions of podilia area in Ukraine. Ukrainian Journal of Ecology, 10(1), 210-214.

Telekalo N., Mordvaniuk M., Shafar H., Matsera O. (2019). Agroecological methods of improving the productivity of niche leguminous crops. Ukrainian Journal of Ecology. 9(1), 169-175.

Vdovenko S.A., Palamarchuk I.I., Pantsyreva H.V. (2018). Energy efficient growing of red beet in the conditions of central forest steppe of Ukraine Ukrainian Journal of Ecology, 8, 34-40.

Vdovenko S.A., Pantsyreva H.V., Palamarchuk I.I., Lytvynuk H.V. (2018a). Symbiotic potential of snap beans (Phaseolus vulgaris L.) depending on biological products in agrocoenosis of the RightBank Forest-steppe of Ukraine. Ukrainian journal of Ecology, 8(3), 270-274.

Vdovenko S.A., Procopchuk V.M.., Palamarchuk I.I., Pantsyreva H.V. (2018b). Effectiveness of the application of soil milling in the growing of the squash (Cucurbita pepo var. giraumontia) in the right-benk forest stepp of Ukraine. Ukrainian Journal of Ecology, 8(4), 1-5.

Xing, X., Jiang, H., Zhou, Q., Xing, H., Jiang, H., \& Wang, S. (2016). Improved drought tolerance by early IAA - and ABA-dependent $\mathrm{H}_{2} \mathrm{O}_{2}$ accumulation induced by a-naphthaleneacetic acid in soybean plants. Plant Growth Regulation, 80(3), 303-314.

Yanovych, V., Honcharuk, T., Honcharuk, I. \& Kovalova, K. (2017). Design of the system to control a vibratory machine for mixing loose materials. Eastern-European Journal of Enterprise Technologies, 6(3-90), 4-13.

Yanovych, V., Honcharuk, T., Honcharuk, I. \& Kovalova, K. (2018). Engineering management of vibrating machines for targeted mechanical activation of premix components. INMATEH - Agricultural Engineering, 54(1), 25-32.

Zhao, H., Cao, H., Ming-Zhen, P., Sun, Y., \& Liu, T. (2017). The role of plant growth regulators in a plant aphid parasitoid tritrophic system. Journal of Plant Growth Regulation, 36(4), 868-876.

\section{Citation:}

Didur, I., Bakhmat M., Chynchyk O., Pantsyreva H., Telekalo N., Tkachuk O. (2020). Substantiation of agroecological factors on soybean agrophytocenoses by analysis of variance of the Right-Bank Forest-Steppe in Ukraine. Ukrainian Journal of Ecology, 10 (5), 54-61. 


\section{Appendix}

Table 3. Significance of the influence of variety, norms of mineral fertilizers and sowing method on soybean yield in 2019.

\begin{tabular}{|c|c|c|c|c|c|c|c|c|c|c|c|}
\hline \multirow[t]{2}{*}{ A } & \multirow[t]{2}{*}{$\mathrm{C}$} & \multirow[t]{2}{*}{$\mathrm{B}$} & \multicolumn{2}{|l|}{$\begin{array}{l}\text { Option } \\
\text { number }\end{array}$} & \multirow[t]{2}{*}{$\begin{array}{l}\text { Option } \\
\text { code }\end{array}$} & \multirow[t]{2}{*}{$\bar{x}$} & \multicolumn{3}{|c|}{ The difference in factors } & \multirow[t]{2}{*}{$\mathrm{LSD}_{0.05}$} & \multirow[t]{2}{*}{$\begin{array}{l}\mathrm{s}^{\bar{x}} \\
\%\end{array}$} \\
\hline & & & & & & & $A$ & $\mathrm{C}$ & $\mathrm{B}$ & & \\
\hline \multirow[t]{8}{*}{ Podilska 1} & $15 \mathrm{~cm}$ & $\begin{array}{l}\text { without fertilizers } \\
\text { (c) }\end{array}$ & 1 & 0 & 1.77 & - & - & - & 028 & 3.83 & \\
\hline & & $\mathrm{P} 60 \mathrm{~K} 30+(\mathrm{N} 15)$ & 2 & B & 1.86 & - & - & 0.09 & & & \\
\hline & & N30P60K30 + (N15) & 3 & B1 & 2.43 & - & - & 0.66 & & & \\
\hline & & $\mathrm{N} 45 \mathrm{P} 60 \mathrm{~K} 30+(\mathrm{N} 15)$ & 4 & B2 & 2.51 & - & - & 0.74 & & & \\
\hline & $45 \mathrm{~cm}$ & without fertilizers & 5 & $\mathrm{C}$ & 2.90 & - & 1.13 & - & & & \\
\hline & & $\mathrm{P} 60 \mathrm{~K} 30+(\mathrm{N} 15)$ & 6 & $\mathrm{BC}$ & 3.05 & - & 1.19 & 0.15 & & & \\
\hline & & N30P60K30 + (N15) & 7 & B1C & 2.63 & - & 0.2 & -0.27 & & & \\
\hline & & $\mathrm{N} 45 \mathrm{P} 60 \mathrm{~K} 30+(\mathrm{N} 15)$ & 8 & $\mathrm{~B} 2 \mathrm{C}$ & 2.87 & - & 0.36 & -0.03 & & & \\
\hline \multirow[t]{8}{*}{ Podilska 416} & $15 \mathrm{~cm}$ & without fertilizers & 9 & $A$ & 1.98 & 0.21 & - & - & & & \\
\hline & & $\mathrm{P} 60 \mathrm{~K} 30+(\mathrm{N} 15)$ & 10 & $A B$ & 2.23 & 0.37 & - & 0.25 & & & \\
\hline & & N30P60K30 + (N15) & 11 & $\mathrm{AB} 1$ & 2.66 & 0.23 & - & 0.68 & & & \\
\hline & & $\mathrm{N} 45 \mathrm{P} 60 \mathrm{~K} 30+(\mathrm{N} 15)$ & 12 & $\mathrm{AB} 2$ & 2.67 & 0.16 & - & 0.69 & & & \\
\hline & $45 \mathrm{~cm}$ & without fertilizers & 13 & $A C$ & 2.98 & 0.08 & 1.0 & - & & & \\
\hline & & $\mathrm{P} 60 \mathrm{~K} 30+(\mathrm{N} 15)$ & 14 & $A B C$ & 3.19 & 0.14 & 0.96 & 0.21 & & & \\
\hline & & N30P60K30 + (N15) & 15 & $\mathrm{AB} 1 \mathrm{C}$ & 2.89 & 0.26 & 0.23 & -0.09 & & & \\
\hline & & $\mathrm{N} 45 \mathrm{P} 60 \mathrm{~K} 30+(\mathrm{N} 15)$ & 16 & $\mathrm{AB} 2 \mathrm{C}$ & 3.13 & 0.26 & 0.46 & 0.15 & & & \\
\hline \multirow[t]{8}{*}{ Chernivetska 9} & $15 \mathrm{~cm}$ & without fertilizers & 17 & $\mathrm{~A} 1$ & 1.73 & -0.04 & - & - & & & \\
\hline & & $\mathrm{P} 60 \mathrm{~K} 30+(\mathrm{N} 15)$ & 18 & $A 1 B$ & 1.91 & 0.05 & - & 0.18 & & & \\
\hline & & N30P60K30 + (N15) & 19 & A1B1 & 2.38 & -0.05 & - & 0.65 & & & \\
\hline & & $\mathrm{N} 45 \mathrm{P} 60 \mathrm{~K} 30+(\mathrm{N} 15)$ & 20 & A1B2 & 2.55 & 0.04 & - & 0.82 & & & \\
\hline & $45 \mathrm{~cm}$ & without fertilizers & 21 & $\mathrm{~A} 1 \mathrm{C}$ & 2.94 & 0.04 & 1.21 & - & & & \\
\hline & & $\mathrm{P} 60 \mathrm{~K} 30+(\mathrm{N} 15)$ & 22 & $\mathrm{~A} 1 \mathrm{BC}$ & 2.85 & -0.2 & 0.94 & -0.09 & & & \\
\hline & & N30P60K30 + (N15) & 23 & $\mathrm{~A} 1 \mathrm{~B} 1 \mathrm{C}$ & 2.95 & 0.32 & 0.57 & 0.01 & & & \\
\hline & & $\mathrm{N} 45 \mathrm{P} 60 \mathrm{~K} 30+(\mathrm{N} 15)$ & 24 & $\mathrm{~A} 1 \mathrm{~B} 2 \mathrm{C}$ & 2.87 & 0 & 0.32 & -0.07 & & & \\
\hline \multirow[t]{8}{*}{ Agate } & $15 \mathrm{~cm}$ & without fertilizers & 25 & $\mathrm{~A} 2$ & 1.61 & -0.16 & - & - & & & \\
\hline & & $\mathrm{P} 60 \mathrm{~K} 30+(\mathrm{N} 15)$ & 26 & $A 2 B$ & 1.96 & 0.1 & - & 0.35 & & & \\
\hline & & N30P60K30 + (N15) & 27 & A2B1 & 2.15 & -0.28 & - & 0.54 & & & \\
\hline & & N45P60K30 + (N15) & 28 & $\mathrm{~A} 2 \mathrm{~B} 2$ & 2.67 & 0.16 & - & 1.06 & & & \\
\hline & $45 \mathrm{~cm}$ & without fertilizers & 29 & $\mathrm{~A} 2 \mathrm{C}$ & 2.80 & -0.1 & 1.19 & - & & & \\
\hline & & $\mathrm{P} 60 \mathrm{~K} 30+(\mathrm{N} 15)$ & 30 & $\mathrm{~A} 2 \mathrm{BC}$ & 3.07 & 0.02 & 1.11 & 0.27 & & & \\
\hline & & N30P60K30 + (N15) & 31 & $\mathrm{~A} 2 \mathrm{~B} 1 \mathrm{C}$ & 2.57 & -0.06 & 0.42 & -0.23 & & & \\
\hline & & N45P60K30 + (N15) & 32 & $\mathrm{~A} 2 \mathrm{~B} 2 \mathrm{C}$ & 2.93 & 0.06 & 0.26 & 0.13 & & & \\
\hline $\mathrm{LSD}_{0.05}$ for factc & $A, B, C$ & & 0.10 & 0.10 & 0.07 & & & & & & \\
\hline
\end{tabular}

